\title{
Gum Arabic Modifies Glucocorticoid Metabolic Enzymes Gene Associated with Decreased Plasma Corticosterone Levels in Mice
}

\author{
Abdelkareem A Ahmed ${ }^{1-4 *}$, Mohammed Elmujtba Adam Essa ${ }^{4}$, Adriano Mollicad ${ }^{5}$, Azzurra \\ Stefanucci ${ }^{4,5}$, Gokhan Zengin ${ }^{4,6}$, Hussain Ahmed ${ }^{7}$ and Ayman Sati Sati Mohamed ${ }^{4}$ \\ ${ }^{1}$ Department of Physiology and Biochemistry, Faculty of Veterinary Science, University of Nyala, Sudan \\ ${ }^{2}$ Institute of Molecular Biology, University of Nyala, Sudan \\ ${ }^{3}$ Biomedical Research Institute, Darfur University College, Sudan
}

${ }^{4}$ Department of Clinical Medicine, Medical and cancer Research Institute, Sudan

${ }^{5}$ Department of Pharmacy, University “G. d'Annunzio" of Chieti-Pescara, Italy

${ }^{6}$ Department of Biology, Science Faculty, Selcuk University, Konya, Turkey

${ }^{7}$ College of Veterinary and Animal Science, the Islamia University, Bahawalpur, Pakistan

*Corresponding author: Abdelkareem A Ahmed, Department of Physiology and Biochemistry, Faculty of Veterinary Science, University of Nyala, Nyala, 583, Sudan

\section{ARTICLE INFO}

Received: 慧 September 29, 2020

Published: 慧 October 12, 2020

Citation: Abdelkareem A Ahmed, Mohammed Elmujtb Adam Essa, Adriano Mollicad, Azzurra Stefanucci, Gokhan Zengin, et al. Gum Arabic Modifies Glucocorticoid Metabolic Enzymes Gene Associated with Decreased Plasma Corticosterone Levels in Mice. Biomed J Sci \& Tech Res 31(1)-2020. BJSTR. MS.ID.005050.

Keywords: Gum Arabic; Glucocorticoids Receptors Mice; Mineralocorticoid Receptor; $\quad 11 \beta$-Hydroxysteroid Dehydrogenases; Corticosterone

\section{ABSTRACT}

Glucocorticoids (GCs) are a class of stress hormones that play a large number of biological actions in the body. The levels of GCs regulated by the intracellular enzyme $11 \beta$-hydroxysteroid dehydrogenases (11ß-HSD $1 \& 2$ ) and are associated with the pathogenesis of metabolic syndrome. Here we aimed to investigate effect of Gum Arabic (GA) on GCs plasma corticosterone concentrations and its metabolic enzymes gene expression in mice. In the present study, 40 female CD-1 mice of 90 days old were randomly divided into two groups (20 of each group). Control group and GA group offered GA in the form of drink $(10 \% \mathrm{w} / \mathrm{v})$ for 15 weeks. GA in drinking water significantly $(\mathrm{P}<0.05)$ decreased food intake, body weight associated with reduction of visceral adipose tissue. GA supplementation significantly $(\mathrm{P}<0.01)$ decreased blood glucose, total cholesterol, and very low-density lipoprotein (VLDL) whereas increased high-density lipoprotein (HDL) concentrations compared to the control. However, supplementation of GA did not change triglycerides or very LDL. Interestingly, GA significantly $(\mathrm{P}<0.05)$ decreased plasma corticosterone associated with downregulation of hepatic 11ß-HSD1 and glucocorticoid receptor (GR) mRNA expression compared to the control. Conversely, the treatment of GA increased hepatic 11 $\beta$-HSD2 mRNA expression. In addition, the treatment of GA significantly $(\mathrm{P}<0.05)$ decreased muscular $11 \beta-H S D 1$ compared to the control. No changes were observed in muscular GR and mineralocorticoid receptor. In conclusion, GA may enhance metabolic disorders through modification of hepatic 11ß-HSDs mRNA expression which may ameliorate metabolic disorder complications. Further studies required to elucidate the molecular mechanisms of GA on GCs.

\section{Introduction}

Glucocorticoids (GCs), corticosterone in rodents and cortisol in humans are endogenous stress hormones that exert key physiological functions [1] on various tissues [2] including liver [3] and skeletal muscle [4]. GCs affect almost all organs and 
tissues in the body [5], regulating various physiological processes [6] including stress response [7], immune response [8], energy metabolism [9], cell proliferation [10], skeletal muscle growth [11], and reproduction [12]. GCs exert their action through the glucocorticoid receptor (GR) [13], which is a transcription factor that belongs to the superfamily of nuclear hormone receptors [14]. GR acts via different mechanisms $[15,16]$, one of the major mechanisms is transcriptional regulation of its primary target genes through genomic glucocorticoid response elements thereby directly binding to DNA or tethering onto other DNA-binding transcription factors [17]. Their secretion is mainly regulated by the hypothalamic-pituitary-adrenal axis [18].

The bioactivity of GCs is regulated via the intracellular metabolism involving 11 $\beta$-hydroxysteroid dehydrogenases (11 $\beta$-HSDs) and 20-hydroxysteroid dehydrogenase (20HSD) [19]. Elevations of GCs modify metabolic homeostasis such as hypoglycemia [20], infections [21], trauma [22], ambiguous temperature [23] or cold and stressful situations [24]. 11 $\beta$-HSD type 2 catalyzes the interconversion of inactive and active GCs [25]. catalyzes the production of active corticosterone (CORT) from 11-dehydrocorticosterone in rodents, including in liver [26] and muscles [27]. Deregulation regulation of these enzymes has been associated various metabolic disorders including obesity [28], diabetes [29], hypertension [30], and cardiovascular disease [31]. Overexpression of 11 $\beta$-HSD1 in the liver [32] or muscle [33] results in increased GCs action [34] and insulin resistance [35], while targeted downregulation of $11 \beta$-HSD1 protect against insulin resistance [29]. The inhibition of 11 $\beta$-HSD1 decreases intracellular GCs concentrations [36] and thus enhances insulin sensitivity both in murine and mice [36].

On the other hand, the increased activity of $11 \beta$-HSD type 2 resulted in tissue-specific conversion of active cortisol to inactive cortisone [37], thereby decreasing the local of active GCs levels. Deregulation of HSD2 enzyme activity has been associated with a number of metabolic diseases [38]. In addition, inhibition of $11 \beta$ HSD type 2 has been obviously shown to induce a congenital or acquired syndrome of mineralocorticoid exposure [27], thus contribute to essential hypertension [30].

Gum Arabic (GA), an edible dried sticky exudate from Acacia seyal and Acacia senegal is rich in non-viscous soluble fibers [39]. Pharmacologically, GA has been confirmed to have a number of therapeutic benefits including hypoglycemic [40], hypocholesterolemic [41] immunomodulatory [42], antioxidant [43], antiobesity [44], and many other health beneficial [45]. In our pervious publication, we reported that GA decreased visceral adipose tissue which was associated with downregulation of $11 \beta$-Hydroxysteroid dehydrogenase type I in the liver and muscles of mice [46]. To our knowledge, the effect of GA on stress hormone levels is not reported. Therefore, here we hypothesized that the supplementation of GA in the form of drinking water may alter plasma CORT levels in mice. In addition, the alteration in plasma CORT concentration by GA administration may associate with changes in glucocorticoid metabolic enzymes gene and mRNA in liver and muscle of mice. Moreover, it remains unknown whether the changes in 11ß-HSD type 1 and type 2 may be linked with changes in glucocorticoid receptor (GR) and mineralocorticoid receptor (MR) gene mRNA expression.

\section{Materials and Methods}

\section{Animals and Experimental Design}

Forty female albino laboratory mice (age, 90 days) old were obtained from Sudanese National Research Center and housed in 8 plastic cages (each containing 5 mice) in a room kept at $25 \mathrm{C}$ with a 12-h light and dark cycle. The animals were allowed to access freely to a commercial pelleted diet for the adaptation and drinking water throughout the experiment at least for one weekday. After 7 days of adaptation, the animals were divided into two groups of 20 mice in each group. Control group and GA group. GA group was provided drinking water containing GA whereas; the control group was given tape water. These mice received $0.5 \%$ of GA aqueous solution as drinking water for 7 days to adapt GA, and then $10 \%$ solution for a further 15 weeks consecutively. The control group was remained on the same drinking water as in the acclimatization. Body weight and food consumption were recorded throughout the period of the experiment. On day 105, the mice were killed. Liver and visceral adipose tissues were dissected and weighed. The tissue and blood samples were collected and stored at $-80^{\circ} \mathrm{C}$.

\section{Blood Lipid Profile Biochemistry}

Plasma lipids biochemistry including total cholesterol, triglycerides, HDL, VLDL, and LDL were determined using commercially assay kits according to the manufacturers' instructions (Nanjing Jiancheng Bioengineering Company, Nanjing, China).

\section{Blood Glucose Measurement}

Plasma samples were obtained from blood through centrifugation $\left(2,400 \mathrm{rpm}, 20 \mathrm{~min}\right.$, and $\left.3.5^{\circ} \mathrm{C}\right)$ and then stored at $-20{ }^{\circ} \mathrm{C}$ until samples analyzed. Blood glucose concentrations were measured using assay kits according to the manufacturers' instructions. (Nanjing Jiancheng Bioengineering Company, Nanjing, China).

\section{Plasma Corticosterone Measurement}

After decapitation of mice, blood samples were obtained from the ruptured cervical blood vessels in heparinized tubes for corticosterone (CORT). The plasma samples were prepared after centrifugation $\left(2,400 \mathrm{rpm}, 20 \mathrm{~min}, 3.5^{\circ} \mathrm{C}\right)$ in a refrigerated device and frozen at $-20^{\circ} \mathrm{C}$ until the measurement of the hormone. Plasma CORT levels were measured using radioimmunoassay method (RIA), using the CORT commercial kit according to the 
manufacturers' instructions (Biochem Immuno System). All plasma samples were dosed in the same assay, to avoid inter-assay errors. The lower detection limit for CORT was $0.064 \mathrm{ng} / \mathrm{mL}$, with a $4 \%$ intra-assay error.

\section{Real-time PCR and Gene Expression}

About 100 mg of liver and muscle were ground in liquid N2, and a portion of about 50 to $100 \mathrm{mg}$ were used for extraction of RNA using TRIzol total RNA kit (Invitrogen, Biotechnology Co, Ltd, Carlsbad, CA, USA) according to the manufacturer's instruction. Two approaches were taken to ensure that all the total RNA preparations are free of genomic DNA contamination. Firstly, total RNAs were treated with 10 U DNase I (Rnase Free, D2215, Takara, Japan) for 30 $\min$ at $37^{\circ} \mathrm{C}$, and purified according to the manufacturer's protocol. Secondly, the primers for the reference gene were designed to span an intron, so any genomic DNA contamination can be reported easily with an extra product in the melting curves for real-time PCR. For liver and muscle glucocorticoid metabolic genes expression, realtime PCR was performed in Mx3000P (Stratagene, USA) according to the previous publication [46].

Mock RT and No Template Controls were included to monitor the possible contamination of genomic and environmental DNA at both RT and PCR steps. The pooled sample made by mixing equal quantity of RT products (cDNA) from all samples was used for optimizing the PCR condition and tailoring the standard curves for each target gene, and melting curves were performed to ensure a single specific PCR product for each gene. The PCR products were sequenced to validate the identity of the amplicons. Primers specific $11 \beta$-HSD1, 11 $\beta$-HSD2, GR and MR (Table 2) were synthesized by Geneary (Shanghai, China). A mouse GAPDH was used as a reference gene for normalization purposes. The method of $2-\Delta \Delta \mathrm{Ct}$ was used to analyze the real-time PCR data [47]. The mRNA abundances were presented as the fold change relative to the average level of the control group.

\section{Statistical Analysis}

Descriptive statistics analysis was performed to check the normality and homogeneity of variances before using parametric analyses. Body weight, food intake, organs weight, blood lipids profile, CORT, as well as the relative quantitative data of gene expression were analyzed by one-way ANOVA using SPSS 21.0 for Windows, followed by a least-significant difference (LSD) test for individual comparisons. A P-value $\leq 0.05$ was considered significant.

\section{Results}

\section{Body Weight, Food Intake Visceral Adipose Tissue Weight, and Liver Weight}

In the present study, the supplementation of GA significantly $(\mathrm{P}<0.05)$ decreased VAT (Figure $1 \mathrm{~A})$ food intake (Figure $1 \mathrm{~B})$, and body weight (Figure $1 \mathrm{C}$ ) compared to the control group. No significant differences were observed in liver weight regarding the treatment of GA (Figure 1D).

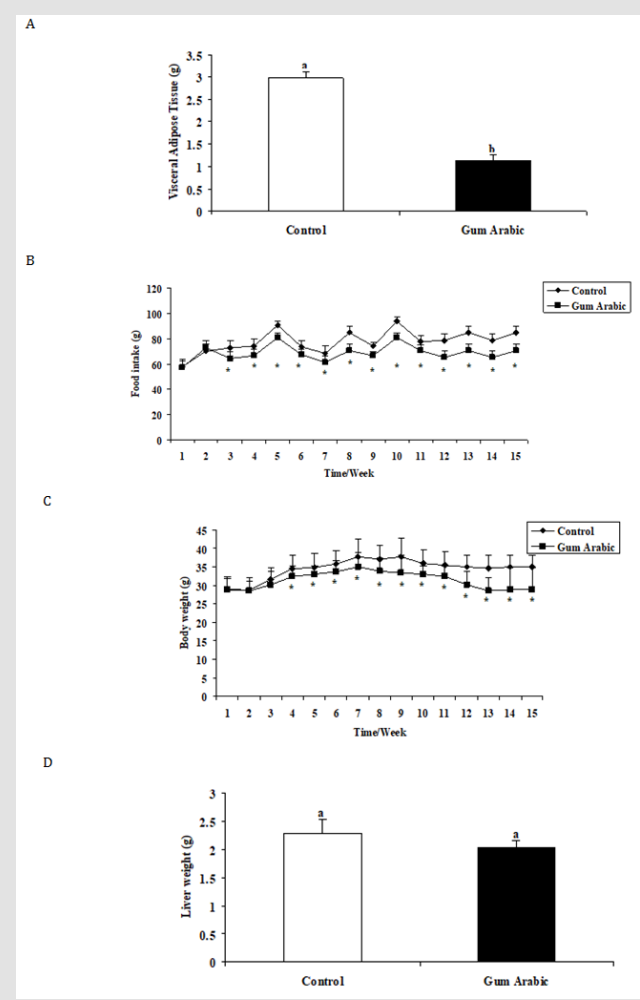

Figure 1: Effect of GA treatments on liver food intake (A) body weight (B), visceral adipose tissue (C) and liver weight (D). The values are the means $\pm S E M, n=20$ /group. 


\section{Blood Glucose Lipid Profile}

In this study, the treatment of GA significantly $(\mathrm{P}<0.05)$ decreased final blood glucose concentration compared to the control group. In addition, the administration of GA significantly $(\mathrm{P}<0.05)$ decreased total cholesterol $(\mathrm{P}<0.05)$ compared to the control group. Likewise, the supplementation of GA significantly reduced plasma LDL-c concentrations compared to the control group. On the other hand, the treatment of GA significantly $(\mathrm{P}<0.05)$ increased HDL-c concentrations when compared to the control group (Table 1). No changes were observed both in triglycerides or VLDL concentrations regarding GA administration.

Table 1: Effect of GA treatments on blood lipid profile and glucose concentrations. Data were expressed as means \pm S.E.M. of 20 /group. Different letters in the rows indicate significantly different mean values at $\mathrm{p}<0.05$

\begin{tabular}{|c|c|c|c|c|c|c|}
\hline Group & Triglyceride (mg/dL) & Total cholesterol (mg/dL) & HDL (mg/dL) & LDL (mg/dL) & VLDL (mg/dL) & Glucose (mmol/L) \\
\hline Control & $42.3 \pm 3.05 \mathrm{a}$ & $74.5 \pm 3.2 \mathrm{a}$ & $53.51 \pm 2.20 \mathrm{a}$ & $73.43 \pm 5.60 \mathrm{a}$ & $11.26 \pm 4.52 \mathrm{a}$ & $8.70 \pm .53 \mathrm{a}$ \\
\hline Gum & $33.4 \pm 1.5 \mathrm{a}$ & $47.3 \pm 2.16 \mathrm{~b}$ & $70.55 \pm 3.11 \mathrm{~b}$ & $31.62 \pm 4.13 \mathrm{~b}$ & $9.32 \pm 0.12 \mathrm{a}$ & $4.30 \pm 0.50 \mathrm{~b}$ \\
\hline
\end{tabular}

\section{Plasma Corticosterone and Blood Glucose Concentrations}

In the current study, the treatment of GA significantly $(\mathrm{P}<0.05)$ decreased plasma CORT concentrations when compared to the control group (Figure 2A). In addition, the administration of GA significantly $(\mathrm{P}<0.05)$ decreased blood glucose compared to the control group (Table 1).

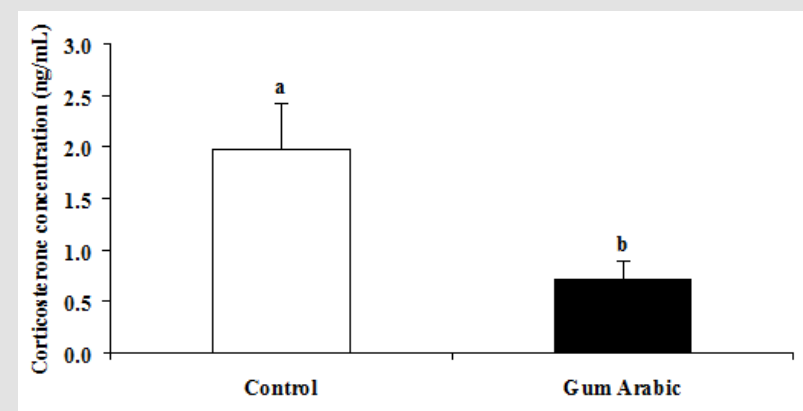

Figure 2: Effect of GA treatments on plasma corticosterone concentrations $(\mathrm{A})$. The values are the means $\pm \mathrm{SEM}$, $n=20$ /group. Bars with different letters are significantly different at $\mathrm{p}<0.05$

Table 2: Primers sequences used for Real-time PCR

\begin{tabular}{|c|c|c|}
\hline $\begin{array}{l}\text { Target } \\
\text { genes }\end{array}$ & $\begin{array}{l}\text { Gene bank } \\
\text { number }\end{array}$ & Primer sequences \\
\hline \multirow{2}{*}{$11 \beta$-HSD1 } & \multirow{2}{*}{ NM_001044751.1 } & F: 5' - TGCAGGTTTTCTTCGTGTGT-3' \\
\hline & & R: 5'- GAGGAGATGACGGCAATGCT-3' \\
\hline \multirow{2}{*}{$11 \beta$-HSD 2} & \multirow{2}{*}{ NM_008289.2 } & F: 5' - ATAGCCCTGGTGCCCTAGAA-3' \\
\hline & & R: 5'- AAGGGCTGAAGAAGCCCATC-3' \\
\hline \multirow[b]{2}{*}{ GR } & \multirow[b]{2}{*}{ X66367.1 } & F: 5'- CGTCGGGGACGGATTCTAAG-3' \\
\hline & & $\begin{array}{c}\text { R: } 5^{\prime}- \\
\text { AAACCGAAAAGGACGCCAGA-3' }\end{array}$ \\
\hline \multirow[t]{2}{*}{ MR } & \multirow[t]{2}{*}{ NM_001083906.2 } & $\begin{array}{c}\text { F: } 5^{\prime}- \\
\text { CACATAAGCAAGACAGTGGCA-3' }\end{array}$ \\
\hline & & R: 5'- TGGTGAACCCTGTGGGAAAC-3' \\
\hline \multirow{2}{*}{ GAPDH } & \multirow{2}{*}{ NM_008084.2 } & $\begin{array}{c}\text { F: } 5^{\prime} \text { - ACATGGTCTACATGTTCCAGTA } \\
-3^{\prime}\end{array}$ \\
\hline & & R: 5'- GGAGTCTACTGGTGTCTTCA-3' \\
\hline
\end{tabular}

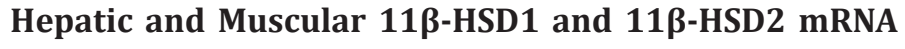

\section{Expression}

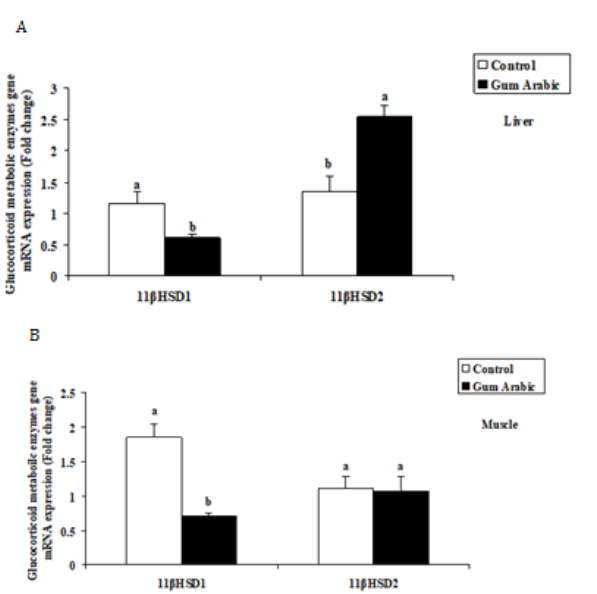

c
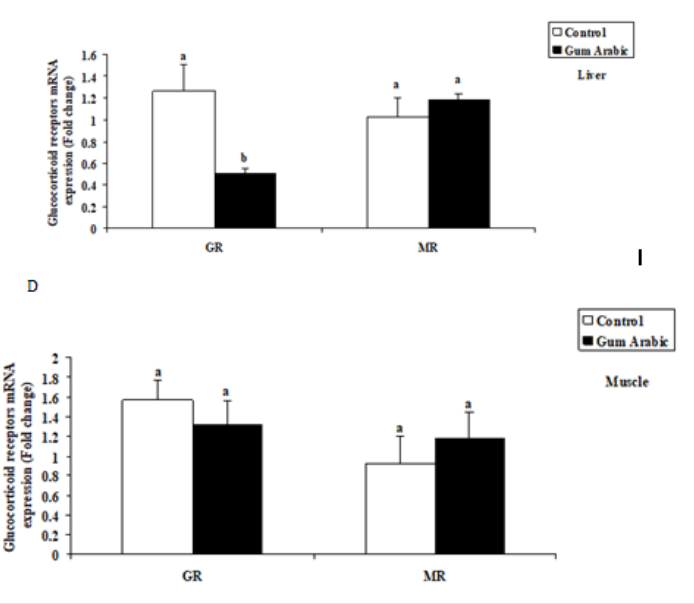

Figure 3: Effect of GA treatments on hepatic 11ßHSD1 and $11 \beta$ HSD2 (A), muscle $11 \beta$ HSD1 and 11ßHSD2 (B), hepatic GR and MR (C) and muscle GR and MR (D) mRNA expression. The values are the means \pm SEM, $n=20$ /group. Bars with different letters are significantly different at $\mathrm{p}<0.05$. 
In the present study, treatment of GA significantly $(\mathrm{P}<0.05)$ decreased hepatic11 $\beta$-HSD1 (Figure 3A) mRNA expression whereas, increased hepatic 11ß-HSD2 (Figure 3A) mRNA expression compared to the control group. Similarly, the treatment of GA significantly $(\mathrm{P}<0.05)$ decreased muscular $11 \beta$-HSD1 (Figure 3B) mRNA expression but not $11 \beta-H S D 2$ (Figure 3B) compared to the control group.

\section{Hepatic and Muscle GR and MR mRNA Expression}

In the present study, the treatment of GA significantly $(\mathrm{P}<0.05)$ decreased hepatic GR (Figure 3C) mRNA expression when compared to the control group. However, no significant differences observed in hepatic MR (Figure 3C) mRNA expression compared to the control group. Likewise, no significant differences were observed both in muscular GR and MR mRNA expression regarding to the treatment of GA (Figure 3D).

\section{Discussion}

There are several reports confirming the association between dietary fibre consumption and stress relief [48-50]. Gum Arabic (GA) is a profitable natural source of dietary fiber that reaches $85 \%$ of its weight [51]. It has a wide spectrum of health benefits including oxidative stress [52], dyslipidemic [41], anti-obesity [53], and anti-inflammatory [54]. In the present study, administration of GA significantly decreased food intake associated with reduction in body weight and blood glucose. These findings are agreed with earlier reports that the treatment of GA associated with a reduction in food intake [36], body weight [55] and blood glucose levels [40]. The reduction effect of GA on food intake and body weight may be due to the fact that several studies confirmed that the dietary fiber have bulk properties [56] and viscosity [57] therefore, it promoting satiety [58], satiation $[59,60]$ and lowering body weight [61].

In addition, intake of dietary fiber associated with increases in satiety and decreased blood glucose levels [61]. Moreover, it was confirmed that supplementation of GA inhibited glucose absorption in intestine through interference of membrane abundance of sodium-glucose transporter 1 in mice [62]. Abdominal obesity is considered the most common signs of metabolic syndrome [63]. As a result, metabolic syndrome is a fatal consequence of visceral obesity [64]. Here we reported that supplementation of GA decreased visceral adipose tissue (VAT) accumulation associated with reduction in blood cholesterol, and VLDL. However, the treatment of GA increased HDL concentrations. Our findings are consistent with previous reports that dietary fibre decreased adiposity [65], lowered blood cholesterol [66] and blood VLDL levels [67]. A variety of mechanisms have been suggested to elucidate the hypercholesterolemic effect of GA $[68,69]$. Some reports suggested that the viscosity of fermentable dietary fibers in GA contribute significantly to lipid lowering action $[65,70]$. In addition, mechanism it was found that administration of GA increased fecal bile acid excretion together with decreased medication in lipid digestion and absorption [71].

Glucocorticoids (GCs) play a vital role in a wide array of physiological processes in the body. The 11ß-hydroxysteroid dehydrogenases (11 $\beta$-HSDs) enzyme catalyze interconversion of intracellular GC in liver [72]. Deregulations of both 11ß-HSD1 and $11 \beta$-HSD2 have been associated with several types of metabolic disorders [73]. In the present study, the supplementation of GA in drinking water downregulated hepatic and muscular 11ß-HSD1 mRNA expression associated with decreases in plasma corticosterone concentrations. These results are consistent with our previous publication showed that administration of GA decreased 11 $\beta$-HSD1 mRNA expression in mice liver [46]. The downregulation of hepatic and muscular 11 $\beta$-HSD1 mRNA may play a critical a role in the inhibition of abdominal adiposity [36] and blood lipid profile, thus may attenuate atherosclerosis [74]. Downregulation of muscular $11 \beta$-HSD1 within the muscle may also protect against the unfavorable effects of local inflammation [75]. However, the mechanism through which GA downregulates $11 \beta$-HSD1 mRNA is unclear the.

Therefore, additional studies are essential to disclose such effects. 11 $\beta$-HSD2 plays a crucial role in the prevention of inappropriate activation of the mineralocorticoid receptor (MR) from improper activation via GCs by inactivating GCs in mineralocorticoid target tissues [76]. In the present study, the treatment of GA upregulated hepatic $11 \beta$-HSD2 mRNA expression. Overexpression of hepatic 11ß-HSD2 mRNA may imply the prevention from various metabolic disorders such as atherogenesis [36], hypertension [77] and proinflammatory changes [76]. Chronic exposure elevated levels of GCs cause metabolic disorders such as insulin resistance [78] elevation of fasting glucose [79] and development of type 2 diabetes mellitus [80]. Here we reported for the first time that the administration of GA decreased GR mRNA expression in the liver but not muscle. Downregulation of hepatic GR mRNA could therefore decrease the development of metabolic risk factors [81] such as obesity [82], cardiovascular diseases [83], and diabetes [84].

\section{Conclusion}

We concluded that the supplementation of GA reduced food intake, body weight, VAT, plasma lipids profile and plasma CORT concentration which were associated with modification of hepatic $11 \beta$-HSD1, 11 $\beta$-HSD2 and GR mRNA expression. Thus, GA may be useful in the treatment of metabolic disorder related diseases that induced by GCs deregulation.

\section{Acknowledgements}

This research did not receive any specific grant from funding agencies in the public, commercial, or not-for-profit sectors. The study is a collaboration projects between University of Nyala, 
Nyala, Sudan, Medical and Cancer Research Institute, Nyala, Sudan; University "G. d'Annunzio" of Chieti-Pescara, Italy; Islamia University, Bahawalpur, Pakistan and National Ribat University, Khartoum, Sudan, Darfur University College, University of Khartoum and Medical and Cancer Research Institute.

\section{References}

1. Kuo T, C Harris, J Wang (2013) Metabolic functions of glucocorticoid receptor in skeletal muscle. Molecular and Cellular Endocrinology 380(1): 79-88.

2. Patel R, Jasmine Williams-Dautovich, Carolyn L Cummins (2014) Minireview: New Molecular Mediators of Glucocorticoid Receptor Activity in Metabolic Tissues. Molecular Endocrinology 28(7): 9991011.

3. Petta I, Lien Dejager, Marlies Ballegeer, Sam Lievens, Jan Tavernier, et al (2016) The Interactome of the Glucocorticoid Receptor and Its Influence on the Actions of Glucocorticoids in Combatting Inflammatory and Infectious Diseases. Microbiology and Molecular Biology Reviews 80(2): 495.

4. Bodine SC, Furlow JD (2015) Glucocorticoids and Skeletal Muscle. Adv Exp Med Biol 872: 145-176.

5. Oakley RH, Cidlowski JA (2013) The biology of the glucocorticoid receptor: new signaling mechanisms in health and disease. The Journal of allergy and clinical immunology 132(5): 1033-1044.

6. Ramamoorthy S, Cidlowski JA (2016) Corticosteroids: Mechanisms of Action in Health and Disease. Rheumatic diseases clinics of North America 42(1): 15-31.

7. Finsterwald C, Alberini CM (2014) Stress and glucocorticoid receptordependent mechanisms in long-term memory: from adaptive responses to psychopathologies. Neurobiology of learning and memory 112: 17-29.

8. Liberman AC, Budzinski ML, Sokn C, Gobbini RP, Steininger A et al. (2018) Regulatory and Mechanistic Actions of Glucocorticoids on T and Inflammatory Cells. Frontiers in endocrinology 9: 235-235.

9. Bordag N, Klie S, Jürchott K, Vierheller J, Schiewe H, et al. (2015) Glucocorticoid (dexamethasone)-induced metabolome changes in healthy males suggest prediction of response and side effects. Scientific Reports 5: 15954.

10. Whirledge S, Dixon D, Cidlowski JA (2012) Glucocorticoids regulate gene expression and repress cellular proliferation in human uterine leiomyoma cells. Hormones \& cancer 3(3): 79-92.

11. Braun TP, Marks DL (2015) The regulation of muscle mass by endogenous glucocorticoids. Frontiers in Physiology 6(12).

12. Whirledge S, Cidlowski JA (2017) Glucocorticoids and Reproduction: Traffic Control on the Road to Reproduction. Trends in endocrinology and metabolism: TEM 28(6): 399-415.

13. Desmet SJ, De Bosscher K (2017) Glucocorticoid receptors: finding the middle ground. J Clin Invest 127(4): 1136-1145.

14. Mazaira GI, Zgajnar NR, Lotufo CM, Becerra CD, Sivils J, et al. (2018) The Nuclear Receptor Field: A Historical Overview and Future Challenges. Nucl Receptor Res 5.

15. Scheschowitsch K, Leite JA, Assreuy J (2017) New Insights in Glucocorticoid Receptor Signaling-More Than Just a Ligand-Binding Receptor. Frontiers in endocrinology 8: 16-16.

16. Cain DW, Cidlowski JA (2015) Specificity and sensitivity of glucocorticoid signaling in health and disease. Best practice \& research. Clinical endocrinology \& metabolism 29(4): 545-556.

17. Hudson WH, Ian Mitchelle S de Vera, Jerome C Nwachukwu, Emily R Weikum, Austin G Herbst, et al. (2018) Cryptic glucocorticoid receptor- binding sites pervade genomic NF-KB response elements. Nature communications 9(1): 1337-1337.

18. Burford NG, Natalia A Webster, Diana Cruz-Topete (2017) HypothalamicPituitary-Adrenal Axis Modulation of Glucocorticoids in the Cardiovascular System. Int J Mol Sci 18(10).

19. Wyrwoll CS, M Holmes, J Secki (2011) 11ß-hydroxysteroid dehydrogenases and the brain: from zero to hero, a decade of progress. Frontiers in neuroendocrinology 32(3): 265-286.

20. Kaur J (2014) A comprehensive review on metabolic syndrome. Cardiology research and practice.

21. Graziadio C, Hasenmajer V, Venneri MA, Gianfrilli D, Isidori AM, et al. (2018) Glycometabolic Alterations in Secondary Adrenal Insufficiency: Does Replacement Therapy Play a Role? Frontiers in endocrinology 9: 434-434.

22. Alarcon JD, Rubiano A, Okonkwo DO, Alarcon J, Martinez-Zapata MJ, et al. (2017) Elevation of the head during intensive care management in people with severe traumatic brain injury. The Cochrane database of systematic reviews 12(12): CD009986-CD009986.

23. Reul JMHM, Collins A, Richard S Saliba, Karen R Mifsud, Sylvia D Carter, et al. (2015) Glucocorticoids, epigenetic control and stress resilience. Neurobiology of Stress 1: 44-59.

24. Mifsud KR, Reul JMHM (2018) Mineralocorticoid and glucocorticoid receptor-mediated control of genomic responses to stress in the brain. Stress 21(5): 389-402.

25. Patel H, Dhangar K, Sonawane Y, Surana S, Karpoormath R, et al. (2018) In search of selective $11 \beta$-HSD type 1 inhibitors without nephrotoxicity: An approach to resolve the metabolic syndrome by virtual based screening. Arabian Journal of Chemistry 11(2): 221-232.

26. Seckl JR, Walker BR (2001) Minireview: 11beta-hydroxysteroid dehydrogenase type 1- a tissue-specific amplifier of glucocorticoid action. Endocrinology 142(4): 1371-1376.

27. Chapman K, M Holmes, J Seckl (2013) 11ß-hydroxysteroid dehydrogenases: intracellular gate-keepers of tissue glucocorticoid action. Physiological reviews 93(3): 1139-1206.

28. Dube S, Norby BJ, Pattan V, Carter RE, Basu A, et al. (2015) $11 \beta$-hydroxysteroid dehydrogenase types 1 and 2 activity in subcutaneous adipose tissue in humans: implications in obesity and diabetes. The Journal of clinical endocrinology and metabolism 100(1): E70-E76.

29. Shukla R, Basu AK, Mandal B, Mukhopadhyay P, Maity A, et al. (2019) $11 \beta$ Hydroxysteroid dehydrogenase - 1 activity in type 2 diabetes mellitus: a comparative study. BMC endocrine disorders 19(1): 15.

30. Ferrari $P$ (2010) The role of 11ß-hydroxysteroid dehydrogenase type 2 in human hypertension. Biochimica et Biophysica Acta (BBA) - Molecular Basis of Disease 1802(12): 1178-1187.

31. Gray GA, Christopher I White, Raphael F P Castellan, Sara J McSweeney, Karen E Chapman (2016) Getting to the heart of intracellular glucocorticoid regeneration: 11ß-HSD1 in the myocardium. Journal of molecular endocrinology 58(1): R1-R13.

32. Dube S, Michael Q Slama, Ananda Basu, Robert A Rizza, Rita Basu (2015) Glucocorticoid Excess Increases Hepatic 11ß-HSD-1 Activity in Humans: Implications in Steroid-Induced Diabetes. The Journal of clinical endocrinology and metabolism 100(11): 4155-4162.

33. Morgan SA, Sherlock M, Gathercole L, Lavery G, Lenaghan C, et al. (2009) 11beta-hydroxysteroid dehydrogenase type 1 regulates glucocorticoidinduced insulin resistance in skeletal muscle. Diabetes 58(11): 25062515

34. Morgan SA, Emma L McCabe, Laura L Gathercole, Zaki K Hassan Smith, Dean P Larner, et al. (2014) 11ß-HSD1 is the major regulator of the 
tissue-specific effects of circulating glucocorticoid excess. Proceedings of the National Academy of Sciences of the United States of America 111(24): E2482-E2491.

35. Schnackenberg CG (2013) Chronic inhibition of $11 \beta$-hydroxysteroid dehydrogenase type 1 activity decreases hypertension, insulin resistance, and hypertriglyceridemia in metabolic syndrome. BioMed research international pp. 427640-427640.

36. Chang LL, Wan-Song Alfred Wun, Paulus S Wang (2018) An inhibitor of 11- $\beta$ hydroxysteroid dehydrogenase type 1 (PF915275) alleviates nonylphenol-induced hyperadrenalism and adiposity in rat and human cells. BMC pharmacology \& toxicology 19(1): 45-45.

37. Krozowski Z, KXZ Li, K Koyama, RE Smith, VR Obeyesekere, et al. (1999) The type I and type II 11beta-hydroxysteroid dehydrogenase enzymes. J Steroid Biochem Mol Biol 69(1-6): 391-401.

38. Iozzo P, Holmes MC, Schmidt M, Cirulli F, Guzzardi MA, et al. (2014) Developmental ORIgins of Healthy and Unhealthy AgeiNg: the role of maternal obesity-introduction to DORIAN. Obesity facts 7(2): 130-151.

39. Slavin J (2013) Fiber and prebiotics: mechanisms and health benefits. Nutrients 5(4): 1417-35.

40. Roozbeh N, Darvish L, Abdi F (2017) Hypoglycemic effects of Acacia nilotica in type II diabetes: a research proposal. BMC research notes 10(1): 331-331.

41. Mohamed RE, Rima E Mohamed, Mohammed O Gadour (2015) The lowering effect of Gum Arabic on hyperlipidemia in Sudanese patients. Front Physiol 6: 160.

42. Sekhon BK, Roubin RH, Yiming Li, Parimala B Devi, Nammi S, et al. (2016) Evaluation of Selected Immunomodulatory Glycoproteins as an Adjunct to Cancer Immunotherapy. PloS one 11(1): e0146881-e0146881.

43. Mirghani M, Ahmed AM Elnour, Kabbashi NA, Md Z Alam, Musa KH, et al. (2018) Determination of antioxidant activity of gum Arabic: An exudation from two different locations. Science Asia 44(3): 179

44. Ushida K (2012) Gum Arabic and its Anti-obese Effect. In Gum Arabic, pp. 285-290.

45. Ahmed AA (2018) 16 - Health Benefits of Gum Arabic and Medical Use. In Gum Arabic (Mariod, A.A. ed), pp. 183-210.

46. Ahmed AA, Hassan H Musa, Jaafar S Fedail, Amal Z Sifaldin, Taha H Musa (2015) Gum arabic decreased visceral adipose tissue associated with downregulation of $11 \beta$-hydroxysteroid dehydrogenase type I in liver and muscle of mice. Bioactive Carbohydrates and Dietary Fibre 6(1): 31 36.

47. Livak KJ, Schmittgen TD (2001) Analysis of relative gene expression data using real-time quantitative PCR and the 2(-Delta Delta C(T)) Method. Methods 25(4): 402-408.

48. Al-Dujaili AE, S Ashmore (2019) A Short Study Exploring the Effect of the Glycaemic Index of the Diet on Energy intake and Salivary Steroid Hormones. Nutrients 11(2).

49. Rushen J, S Ashmore (2016) Effects of an oat-based high-fibre diet on insulin, glucose, cortisol and free fatty acid concentrations in gilts. Animal Science 69(2): 395-401.

50. Laugero KD, Luis M Falcon, Katherine L Tucker (2011) Relationship between perceived stress and dietary and activity patterns in older adults participating in the Boston Puerto Rican Health Study. Appetite 56(1): 194-204.

51. Mariod AA (2018) 20 - Gum Arabic Dietary Fiber. In Gum Arabic (Mariod, A.A. ed), pp. 237-243.

52. Ahmed AA, Jaafar S Fedail, Hassan H Musa, Asghar Ali Kamboh, Amal Z Sifaldin, et al. (2015) Gum Arabic extracts protect against hepatic oxidative stress in alloxan induced diabetes in rats. Pathophysiology 22(4): 189-194.
53. Ahmed AA, Hassan H Musa, Jafaar S Fedail, Amal Z Sifaldin, Taha H Musa (2016) Gum arabic suppressed diet-induced obesity by alteration the expression of mRNA levels of genes involved in lipid metabolism in mouse liver. Bioactive Carbohydrates and Dietary Fibre 7(1): 15-20.

54. Kamal E, Gadir Kaddam LA, Maha Dahawi, Montaser Osman, Salih MA, et al. (2018) Gum Arabic Fibers Decreased Inflammatory Markers and Disease Severity Score among Rheumatoid Arthritis Patients, Phase II Trial. International Journal of Rheumatology.

55. Babiker R, Tarig H Merghani, Khalifa Elmusharaf, Rehab M Badi, Florian Lang, et al. (2012) Effects of Gum Arabic ingestion on body mass index and body fat percentage in healthy adult females: two-arm randomized, placebo controlled, double-blind trial. Nutr J 11: 111.

56. Tan C, Wei H, Zhao X, Xu C, Peng J (2017) Effects of dietary fibers with high water-binding capacity and swelling capacity on gastrointestinal functions, food intake and body weight in male rats. Food Nutr Res 61(1): 1308118.

57. Dikeman CL, Fahey GC (2006) Viscosity as related to dietary fiber: a review. Crit Rev Food Sci Nutr 46 (8): 649-663.

58. Warrilow A, Duane Mellor, Andrew McKune, Kate Pumpa (2019) Dietary fat, fibre, satiation, and satiety-a systematic review of acute studies. Eur J Clin Nutr 73(3): 333-344.

59. Salleh SN, Hamizi Fairus AA, Zahary MN, Raj NB, Mhd Jalil AM (2019) Unravelling the Effects of Soluble Dietary Fibre Supplementation on Energy Intake and Perceived Satiety in Healthy Adults: Evidence from Systematic Review and Meta-Analysis of Randomised-Controlled Trials. Foods 8(1): 15.

60. Warrilow A, Duane Mellor, Andrew McKune, Kate Pumpa (2019) Dietary fat, fibre, satiation, and satiety-a systematic review of acute studies. European Journal of Clinical Nutrition 73(3): 333-344.

61. Thompson SV, Bridget A Hannon, Ruopeng An, Hannah D Holscher (2017) Effects of isolated soluble fiber supplementation on body weight, glycemia, and insulinemia in adults with overweight and obesity: a systematic review and meta-analysis of randomized controlled trials. Am J Clin Nutr 106(6): 1514-1528.

62. Nasir O, Artunc F, Wang K, Rexhepaj R, Föller M, et al. (2010) Downregulation of mouse intestinal $\mathrm{Na}(+)$-coupled glucose transporter SGLT1 by gum arabic (Acacia Senegal). Cell Physiol Biochem 25(2-3): 203-10.

63. Paley CA, Johnson MI (2018) Abdominal obesity and metabolic syndrome: exercise as medicine? BMC sports science, medicine \& rehabilitation 10(1): 7 .

64. Lopes HF, Correa-Giannella ML, Consolim-Colombo FM, Egan BM (2016) Visceral adiposity syndrome. Diabetology \& metabolic syndrome 8: 40.

65. Brockman DA, Xiaoli Chen, Daniel D Gallaher (2014) High-viscosity dietary fibers reduce adiposity and decrease hepatic steatosis in rats fed a high-fat diet. J Nutr 144(9): 1415-1422.

66. Narayan S, Lakshmipriya N, Vaidya R, Ramya Bai M, Sudha V, et al. (2014) Association of dietary fiber intake with serum total cholesterol and lowdensity lipoprotein cholesterol levels in Urban Asian-Indian adults with type 2 diabetes. Indian journal of endocrinology and metabolism 18(5): 624-630.

67. Hannon BA, Sharon V Thompson, Caitlyn G Edwards, Sarah K Skinner, Grace M Niemiro, et al. (2018) Dietary Fiber Is Independently Related to Blood Triglycerides Among Adults with Overweight and Obesity. Current Developments in Nutrition 3(2).

68. Kelley JJ, Tsai AC (1978) Effect of pectin, gum arabic and agar on cholesterol absorption, synthesis, and turnover in rats. J Nutr 108(4): 630-639.

69. Moundras C, Behr SR, Demigne C, Mazur A, C Remesy (1994) Fermentable polysaccharides that enhance fecal bile acid excretion lower plasma 
cholesterol and apolipoprotein E-rich HDL in rats. J Nutr 124(11): 217988.

70. Schroeder N, Len F Marquart, Gallaher DD (2013) The role of viscosity and fermentability of dietary fibers on satiety- and adiposity-related hormones in rats. Nutrients 5(6): 2093-2113.

71. Eastwood MA (1992) The Physiological Effect of Dietary Fiber: An Update. Annual Review of Nutrition 12: 19-35.

72. Stimson RH, Ruth Andrew, Norma C McAvoy, Dhiraj Tripathi, Peter C Hayes, et al. (2011) Increased Whole-Body and Sustained Liver Cortisol Regeneration by $11 \beta$-Hydroxysteroid Dehydrogenase Type 1 in Obese Men with Type 2 Diabetes Provides a Target for Enzyme Inhibition. Diabetes 60(3): 720-725.

73. Bailey MA (2017) 11ß-Hydroxysteroid Dehydrogenases and Hypertension in the Metabolic Syndrome. Current hypertension reports 19(12): 10-100.

74. Garcia RA, Debra J Search, John A Lupisella, Jacek Ostrowski, Bo Guan, et al. (2013) 11ß-Hydroxysteroid Dehydrogenase Type 1 Gene Knockout Attenuates Atherosclerosis and In Vivo Foam Cell Formation in Hyperlipidemic apoE-/- Mice. PLOS ONE 8(2): e53192.

75. Hardy RS, Craig L Doig, Zahrah Hussain, Mary O'Leary, Stuart A Morgan, et al. (2016) 11ß-Hydroxysteroid dehydrogenase type 1 within muscle protects against the adverse effects of local inflammation. The Journal of pathology 240(4): 472-483.

76. Hadoke PWF, Kipari T, Seckl JR, Chapman KE (2013) Modulation of $11 \beta$-hydroxysteroid dehydrogenase as a strategy to reduce vascular inflammation. Current atherosclerosis reports 15(5): 320-320.

77. Tapia-Castillo A, Cristian A Carvajal, Fidel Allende, Carmen Campino, Carlos E Fardella (2017) Hypertensive Patients That Respond to

\section{ISSN: 2574-1241}

DOI: $10.26717 /$ BJSTR.2020.31.005050

Abdelkareem A Ahmed. Biomed J Sci \& Tech Res

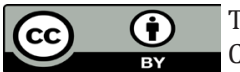

This work is licensed under Creative Commons Attribution 4.0 License

Submission Link: https://biomedres.us/submit-manuscript.php
Aldosterone Antagonists May Have a Nonclassical 11ß-HSD2 Deficiency. American Journal of Hypertension 30(8): e6-e6.

78. Zhou PZ, Zhu YM, Zou GH, Sun YX, Xiu XL, et al. (2016) Relationship Between Glucocorticoids and Insulin Resistance in Healthy Individuals. Medical science monitor. International Medical Journal of Experimental and Clinical Research 22: 1887-1894.

79. Kamba A, Daimon M, Murakami H, Otaka H, Matsuki K, et al. (2016) Association between Higher Serum Cortisol Levels and Decreased Insulin Secretion in a General Population. PloS one 11(11): e0166077-e0166077.

80. Suh S, Park MK (2017) Glucocorticoid-Induced Diabetes Mellitus: An Important but Overlooked Problem. Endocrinology and metabolism (Seoul, Korea) 32(2): 180-189.

81. Sekgala MD, Zandile J Mchiza, Whadi-ah Parker, Kotsedi D Monyeki (2018) Dietary Fiber Intake and Metabolic Syndrome Risk Factors among Young South African Adults. Nutrients 10(4): 504

82. Hadrévi J, Sogaard K, Christensen JR (2017) Dietary Fiber Intake among Normal-Weight and Overweight Female Health Care Workers: An Exploratory Nested Case-Control Study within FINALE-Health. Journal of nutrition and metabolism pp. 1096015-1096015.

83. Anderson JW, Pat Baird, Richard H Davis, Stefanie Ferreri, Mary Knudtson, et al. (2009) Health benefits of dietary fiber. Nutr Rev 67(4): 188-205.

84. Weickert MO, Pfeiffer AFH (2018) Impact of Dietary Fiber Consumption on Insulin Resistance and the Prevention of Type 2 Diabetes. J Nutr 148(1): 7-12.

$\begin{array}{ll}\text { BIOMEDICAL } & \text { Assets of Publishing with us } \\ \text { RESEARCHES } & \text { - Global archiving of articles } \\ \text { - Immediate, unrestricted online access } & \text { - Rigorous Peer Review Process } \\ & \text { - Authors Retain Copyrights } \\ & \end{array}$

